\title{
PREVENTION OF TUBERCULOSIS AT SCHOOL AGE-AWARENESS OF SECONDARY SCHOOL STUDENTS
}

\author{
Gabriela Tsankova ${ }^{1}$, Bisera Yustiniyanova ${ }^{1}$, Lyusi Kapreljan ${ }^{2}$ \\ ${ }^{1}$ Medical University of Varna, Bulgaria \\ ${ }^{2}$ Humboldt-University of Berlin, Germany
}

\section{SUMMARY}

Aim: to study secondary school students' health awareness of tuberculosis characteristics and its prophylaxis.

Materials and methods: a confidential 32-item questionnaire was filled in by 190 students at the age of $15-18,69(36 \%)$ of who - boys and 121 (64\%) girls in IX, X, XI classes, from 3 different secondary schools in Varna. The questionnaire consists of 32 questions, classified in 4 sections.

SPSS ver. 19.0 software package was used for statistical data processing.

Results: Studies show that the interviewed students are aware of the basic characteristics of tuberculosis. The research displays significant differences between girls' answers and boys' answers. Boys are better informed about the causes, the processes of disease transmission and the basic prophylactic measures for prevention of tuberculosis whereas girls are more knowledgeable about the main symptoms of the disease.

Key words: tuberculosis, risk factors, prevention

Tuberculosis is the first infectious disease reported by the World Health Organization as a global threat to health [6]. According to the experts of the World Health Organization every other person in the world is infected with tuberculosis, and $5 \%$ of them will develop the disease in the next 5 years, unless they are diagnosed and properly treated [1]. The basic ways of getting control of tuberculosis are: early diagnosis of the infected and bacillus secretors, adequate treatment, regular BCG vaccination, as well as raising students' health awareness and students' knowledge of the disease [2]. According to the records of the Regional Health Inspectorate -Varna in 2010, an increased morbidity rate among citizens at 8-9 years of age has been noticed, as compared with the previous two years. During 2008 and 2009 in the region of Varna 3 (6 per 100,000) cases of tuberculosis were registered while in 2010 the number of patients with tuberculosis was 13 (30 per 100,000).

Considering the public health and social importance of the problem, we have set ourselves the AIM: to carry out research of secondary school students' health awareness in relation to tuberculosis characteristics, its prophylaxis and to investigate possible gender differences.

\section{MATERIALS AND METHODS}

A confidential questionnaire was designed that was filled in by 190 students at the age of $15-18$, out of whom, $69(36 \%)$ boys and $121(64 \%)$ girls in IX, X, XI classes, from 3 different secondary schools in Varna.

The questionnaire consists of 32 questions, classified in 4 sections.

SPSS ver. 19.0 software package was used for statistical data processing.

\section{RESULTS AND ANALYSIS}

Tuberculosis is a chronic disease of a recurring character. A number of various factors influence its incidence. According to the interviewees, the most significant of them are: lessened power of resistance to infection (94\%), poor hygiene and unsanitary living conditions $(72 \%)$, unhealthy nutrition $(46 \%)$, chronic stress (21\%), experienced serious infectious diseases, $(43 \%)$, tobacco smoking (63\%), alcohol abuse (31\%), etc. Girls have relatively better knowledge in comparison with boys $(p<0.05)$ (Figure 2). This information is similar to the data we gathered from another questionnaire of ours, which was conducted among students from the Medical College in Varna [5]. 


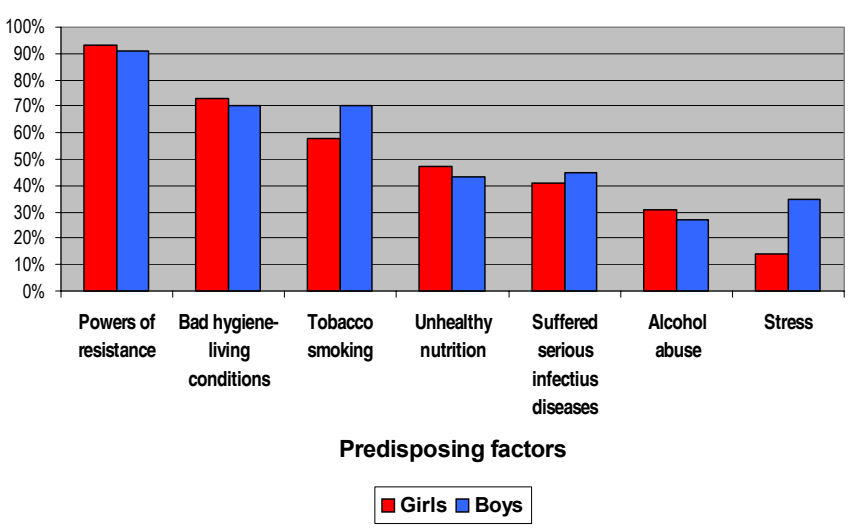

Fig. 1. High school students' knowledge of the predisposing factors for the development of tuberculosis

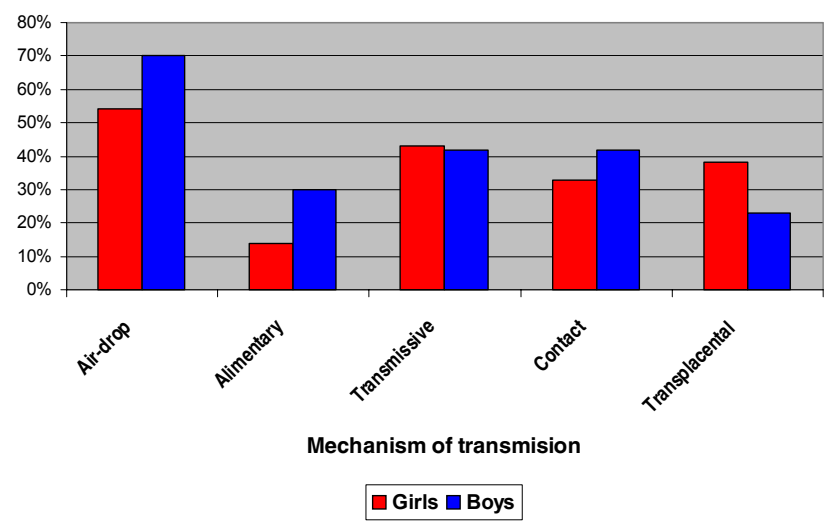

Fig. 2. Public health acquaintance with mechanism of transmission

The data collected through the questionnaire shows that $64 \%$ of the students believe that the people infected with chronic bronchitis, pneumoconiosis and pneumofibrosis are at high risk of developing TB, $32 \%$ of the students have also pointed out HIV-infected patients and those who have been on cortisone preparations for a long time. According to $89 \%$ of the interviewees, tuberculosis patients and bacillus secretors are the most frequent source of infection, $11 \%$ think that the cause of infection are the cows sick from tuberculosis, $6 \%$ of students put the source of infection down to birds and pigs with tuberculosis, and $19 \%$ mention also ticks as a source of the infection, which demonstrates the gaps in their knowledge. $5 \%$ of the interviewed students report on family members having been cured of tuberculosis.

Analysis of the data shows that the airborne transmission of the infection was what they knew best, which was indicated by $70 \%$ of the boys and $54 \%$ of the girls. $38 \%$ of the girls and $23 \%$ of the boys have heard of the transplacental mechanism (from the mother to the fetus),
$30 \%$ of the boys and $14 \%$ of the girls knew about the mechanism of transmission through the alimentary tract. Boys have better knowledge about the mode of transmission of the infection (Figure 2). The results are approximately the same as the ones reported by other researchers [4].

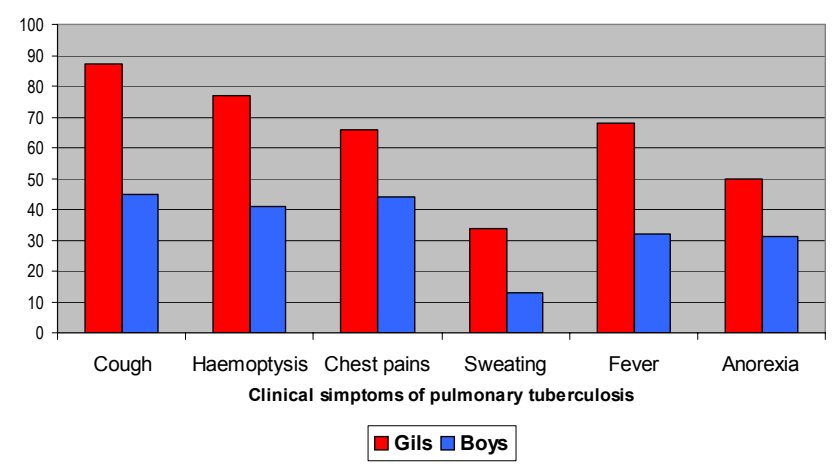

Fig. 3. Public health knowledge of the clinical symptoms of pulmonary tuberculosis

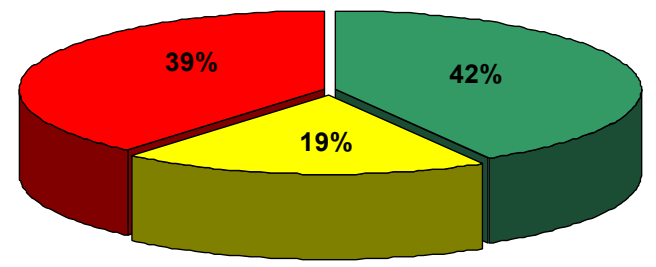

$\square$ Immunized $\square$ Not immunized $\square$ Unaware of having undergone vaccination

Fig. 4. High school students' knowledge of BCG immunization

The better part of the students from the three high schools are aware of the clinical symptoms of pulmonary tuberculosis: cough, lasting for 2-3 weeks or more. These symptoms have been pointed out by $71 \%$ of the students in total ( $73 \%$ girls and $68 \%$ boys), bloody expectorations $63 \%$ (65\% girls and $62 \%$ boys), chest pains- $60 \%$ (56\% girls and $67 \%$ boys). Comparatively speaking, girls tend to be better informed than boys. $42 \%$ of the interviewed have answered incorrectly that jaundice is the basic symptom of tuberculosis, which is an indicator showing a gap in their health education (Figure 3).

$83 \%(90 \%$ of who girls and $79 \%$ boys) have mentioned keeping high level of personal and public hygiene as basic prophylactic measures for tuberculosis prevention.

$69 \%$ (of who $82 \%$ boys and $68 \%$ girls) - have pointed out avoiding contact with tuberculosis patients, $66 \%$ (of who $24 \%$ boys and $41 \%$ girls) - healthy diet, while $65 \%$ (of who $74 \%$ - boys and 59\%- girls) - have emphasized the importance of fitness and sport.

Bearing in mind the high resistance of tubercular 
bacteria and their ability to remain intact in a nutritious medium in room temperature for up to several months, the fact that only $29 \%$ of the interviewed students point out food heat treatment as a preventive factor is quite alarming. According to $19 \%$ of the students pasteurized milk should be boiled for at least five minutes. In comparison with girls, boys are better acquainted with the basic prophylactic precautions.

Despite the fact that BCG (introduced in 1928) is the most effective method of protection against tuberculosis, $39 \%$ of the students were not really aware of the fact whether they have been immunized or not, $19 \%$ reported they were not immunized. (Figure 4).

Students happen to be better acquainted with the tuberculin skin test applied in a pre-vaccination investigation of children at the age of 7,11 and 17. Among the total of 190 students who have been surveyed, $72 \%$ report of having had a tuberculin skin test $-41 \%$ of who have had their test read by their GPs, while $59 \%$ had their results checked by a specialist working at the dispensary for the prevention of tuberculosis.
According to the International Standards of Tuberculosis Care those who are in close contact with tuberculosis should be investigated and kept under control [3].

Concerning the question "What preventive measures should be taken in relation to the contacts of persons with tuberculosis?, $82 \%$ of the students have pointed out BCG vaccination, $60 \%$ note that tuberculin skin test and microbiological investigation are necessary. Only $16 \%$ of the students emphasize the importance of chemoprevention.

\section{CONCLUSION}

Studies show that the interviewed students are aware of the basic characteristics of tuberculosis. The research displays significant gender differences between girls' answers and boys' answers. Boys are better informed of the causes, the processes of disease transmission and the basic prophylactic measures for prevention of tuberculosis, whereas girls are more knowledgeable about the main symptoms of the disease. Similar results have been obtained in a study carried out in Tehran [4].

\section{ANONYMOUS INQUIRY}

You should answer all the questions some of which may have more than one answer. Put a cross (X) next to the correct statements.

Thank you for your time!

The aim of this inquiry examination is to investigate the level of health awareness about tuberculosis and its prophylaxis.

\section{Personal information}

1. School

\section{Class}

2. Age

3. Sex

$\square$ boy $\square$ girl

II. Living conditions

III. Risk factors in developing tuberculosis

1. Indicate the predisposing factors for the development of tuberculosis:

$\square$ bad hygiene living conditions

unhealthy nutrition

suffered serious infectious diseases

$\square$ tobacco smoking

$\square$ alcohol abuse

$\square$ stress

$\square$ fatigue

2. Could the lessen power of resistance facilitate the development of tuberculosis?

$$
\square \text { Yes }
$$

$\square$ No
3. Which of the following groups are with increased risk of developing the disease?

$\square$ diabetics

$\square$ the infected with chronic bronchitis, pneumoconiosis, pneumofibrosis

$\square$ HIV-infected person

$\square$ patients with gastrointestinal diseases

$\square$ patients undergone long-lasting cortisone medication

$\square$ chemotherapy patients

4. Which is the source of the infection?

tuberculosis patients and bacillus secretors

$\square$ cows with tuberculosis

$\square$ birds with tuberculosis

$\square$ pigs with tuberculosis

$\square$ ticks

infection:

5. Point out the mechanism of transmission of the

air-drop mechanismвъзд

$\square$ alimentary mechanism

$\square$ transmissive mechanism

$\square$ contact mechanism

$\square$ transplacental mechanism 
6. According to you which are the main clinical symptoms of the lung form of tuberculosis?

$\square$ body temperature over $39^{\circ} \mathrm{C}$

cough, lasting 2-3 weeks and more

$\square$ anorexia

sweating

$\square$ chest pains

$\square$ asthma

$\square$ heamoptysis

$\square$ jaundice

7. Is there anyone in your family who currently undergoes active treatment?
$\square$ Yes
$\square$ No

8. Is any member of your family being cured of?

$\square$ Yes

$\square$ No

\section{PROPHYLAXIS OF TUBERCULOSIS}

1. Have you undergone BCG immunization?

$\square$ Yes

$\square$ No

$\square$ I do not know
2. Have you been made tuberculin skin test?

$\square$ Yes

$\square$ No

I do not know

3. If yes, who has read the test?

$\square$ GPs

$\square$ specialist working at the dispensary for prevention of tuberculosisot

4. Mention the basic prophylactic measures for prevention of tuberculosis:

$\square$ Healthy nutrition

High level of personal and public hygiene

$\square$ Fitness and sport

Heat treatment of foodstuff

- Boiling the pasteurized milk at least five minutes

- Avoiding being in contact with tubercular patient

5. Which prophylactic precautions could be applied to the contact person with tuberculosis?

$\square$ tuberculin skin test

a chemoprevention

口 BCG vaccination

\section{REFERENCES:}

1. Велизарова, С. Диагностична стойност на T SPOT TB при деца с латентна туберкулозна инфекция, Български медиичнски журнал, 4, 2010, №1, 49-53. (in Bulgarian)

2. Вичева, А., М. Алексиева, Информативна стойност на туберкулиновата чувствителност в детска възраст, Български медищински журнал, 2, 2008, №1, 49-52. (in Bulgarian)
3. Златев, А. Международни стандарти за грижи при туберкулоза, Наука Пулмология 2010, 3-4, 59-61. (in Bulgarian)

4. Mohammad Ali Eman Hadi, Maryam Jalilvand, Mina Hadlan, Assesmant of the Amount of Knowledge and Attitude of Tehran High School Students regarding tuberculosis, Tanaffos, 2006, 5(4), 23-28
5. Tsankova, G, Yustiniyanova B, Medical students knowledge of the characteristic features and prevention of tuberculosis, Journal of IMAB. 2010 16(3):48-50. [CrossRef]

6. Zaman K. Tuberculosis: A Global health problem, J Health Popul Nutr. 2010 Apr;28(2):111-113. [PMC free article] [PubMed]

\author{
Address for correspondence: \\ Gabriela Tsankova \\ Prof. Paraskev Stoyanov Medical University of Varna \\ Medical College of Varna \\ 84 Tsar Osvoboditel Str., BG-9002 Varna, Bulgaria \\ E-mail: gabriela_sc@abv.bg
}

